\section{Neuroretinitis secondary to dual infection of Toxoplasma gondii and Bartonella hensalae}

Abdul Rahman Siti-Khadijah ${ }^{1,2}$, Yaakub Azhany ${ }^{1,2}$, Julieana Muhammed ${ }^{1,2}$, Wan-Hazabbah Wan Hitam ${ }^{1,2}$

${ }^{1}$ Department of Ophthalmology, School of Medical Sciences, Health Campus, Universiti Sains Malaysia, Kubang Kerian, Kelantan, Malaysia; ${ }^{2}$ Hospital Universiti Sains Malaysia, Health Campus, Universiti Sains Malaysia, Kubang Kerian, Kelantan, Malaysia

\section{Abstract}

A 73-year-old lady with underlying diabetes presented with acute loss of central vision in the left eye. Examination revealed visual acuity of 6/60 in the left eye with positive relative afferent pupillary defect and optic disc swelling with macular oedema. Right eye visual acuity was $6 / 12$ with unremarkable findings. Optical coherence tomography (OCT) showed elevated macular with ceacocentral field defect on Humphrey visual field. Connective tissue screening and tubercular screening were negative. Serological screening for Toxoplasma sp and Bartonella sp were positive. She was diagnosed as neuroretinitis secondary to both infections and started on oral azithromycin $500 \mathrm{mg}$ once a day and oral corticosteroid. Her final vision improved to $6 / 12$ with normal optic disc and resolved macular oedema.

Keywords: Bartonella hensalae, cat scratch disease, neuroretinitis, Toxoplasma gondii

Correspondence: Azhany Yaakub, MMed (Ophthal) (USM), Department of Ophthalmology, School of Medical Sciences, Health Campus, Universiti Sains Malaysia, 16150 Kubang Kerian, Kelantan, Malaysia.

E-mail: E-mail: azhany@usm.my 


\section{Neuroretinitis berlaku akibat daripada dua gabungan jangkitan Toxoplasma gondii dan Bartonella hensalae}

\section{Abstrak}

Seorang wanita berusia 73 tahun, pengidap diabetes mengadu penglihatannya kabur di bahagian tengah pada mata kiri secara akut. Pemeriksaan menunjukkan ketajaman visual 6/60 pada mata kiri dengan positif kecacatan aferen, cakera optik bengkak dan edema pada makular. Ketajaman visual mata kanan adalah 6/12 dengan penemuan normal. Tomografi koherensi optik (OCT) menunjukkan kawasan makular yang bengkak dengan gangguan medan ceacocentral pada medan penglihatan Humphrey. Pemeriksaan saringan ke atas penyakit tisu konektif dan saringan batuk kering (TB) adalah negatif. Manakala, pemeriksaan serologi untuk Toxoplasma sp dan Bartonella sp adalah positif. Psakit didiagnosis sebagai mengidap neuroretinitis akibat kedua-dua jangkitan, dan rawatan dengan ubatan azithromycin oral $500 \mathrm{mg}$ sekali sehari dan kortikosteroid oral diberikan. Penglihatannya pulih dan meningkat kepada 6/12 dan menunjukkan cakera optik yang normal dan edema makular yang telah surut.

Kata kunci: Bartonella hensalae, Penyakit cakar kucing, neuroretinitis, Toxoplasma gondii

\section{Introduction}

Neuroretinitis is a term which refers to the mixture of optic disc swelling and retinal inflammation, typically involving the macula, commonly due to infection with Bartonella hensalae, which is a gram-negative intracellular bacterium responsible for cat scratch disease (CSD). Humans get infected via contact with cat fleas, or rarely, cat scratches. Although the diagnosis of CSD may be presumed with clinical criteria, serological evidence of anti $B$. hensalae antibodies is diagnostic.

Ocular toxoplasmosis is caused by Toxoplasma gondii, which is an obligate intracellular protozoal parasite which spreads via sporulated oocysts from cats, which are the definitive host. Humans are the intermediate host, and usually get infected transplacentally or through ingestion of undercooked meat containing bradyzoites. The prevalence of toxoplasmosis in Malaysia ranges from $13.9 \%$ to $30.2 \%{ }^{1}$

\section{Case report}

A 73-year-old lady with diabetes and hypertension presented with acute loss of 
central vision in the left eye for 1 week, associated with pain on ocular movement. There was no history of fever, trauma, or headache. She had been scratched by her cat a few months before.

She was afebrile, with normal blood pressure and blood sugar. There were no skin lesions or lymphadenopathy. Visual acuity in the left eye was $6 / 60$, with a positive relative afferent pupillary defect. Fundus examination showed a swollen left disc with an inferior disc haemorrhage. There was macular oedema, which extended to the papillomacular area (Fig. 1). Optical coherence tomography (OCT) revealed intraretinal fluid over the macula extending to the optic disc (Fig. 2). Visual acuity in the right eye was $6 / 12$, with unremarkable findings.

Full blood count, erythrocyte sedimentation rate, renal function test, and liver function test were normal. Tuberculosis screening was negative, as was the autoimmune screening. Titres for both $T$. gondii (IgG: $1677 \mathrm{IU} / \mathrm{mL}$ ) and B. hensalae (IgG: 1:128) were elevated. Humphrey visual field showed caecocentral scotoma in the left eye. Computed tomography showed optic nerve enlargement in the left eye. Patient was diagnosed to have left neuroretinitis secondary to dual infection with Toxoplasmosis sp and Bartonellosis sp.

She was treated with oral azithromycin $500 \mathrm{mg}$ once a day for 4 weeks and intravenous methylprednisolone $250 \mathrm{mg} 4$ times a day for 3 days, followed by oral prednisolone in tapering dose over 4 weeks. Her left visual acuity improved to 6/12 with resolution of the clinical signs (Figs. 3 and 4).

\section{Discussion}

Toxoplasma gondii and Bartonella hensalae may rarely coexist in a feline, causing dual infection. Close proximity with an infected feral cat is the main risk factor. A study done in Iraq among 207 stray cats showed that $30 \%$ are positive for T. gondii, while $15 \%$ are positive for $B$. hensalae, and $6.3 \%$ harbour both organisms. ${ }^{2}$ In 2011 , a local study established that DNA of $B$. hensalae was identified in $11.5 \%$ of fleas, which act as vectors for infection. ${ }^{3}$

Typical CSD presentation is fever, headache, anorexia, nausea, vomiting, and regional lymphadenopathy. In $25 \%$ to $60 \%$ of patients, there is papular or pustular rash at the inoculation site. The prevalence of ocular bartonellosis in CSD is 5-10\%, with neuroretinitis as the most common ocular manifestation. ${ }^{4}$ Other presentations include Parinaud's oculoglandular syndrome and uveitis. In neuroretinitis, a macular star may develop only after one to two weeks of the initial presentation. These typical presentations of CSD were absent in this patient.

The pathophysiology of macular oedema in neuroretinitis is increased permeability of disc vasculature, with fluid exudate into the peripapillary area. Involvement of the papillomacular bundle results in ceococentral scotoma, as in our patient. Non-arteritic ischaemic optic neuropathy was a possible differential diagnosis 


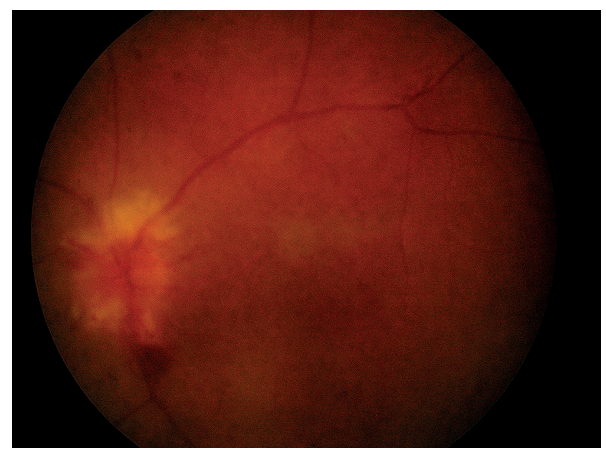

Fig. 1. Left eye fundus photo showing optic disc swelling with inferior disc haemorrhage.

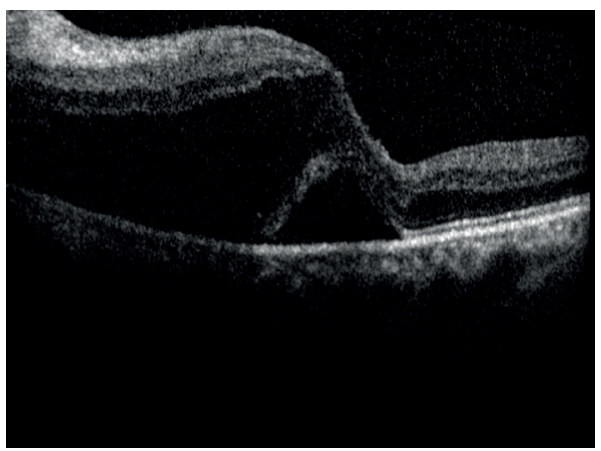

Fig. 2. Left eye OCT showing macular oedema in the papillomacular area at presentation.

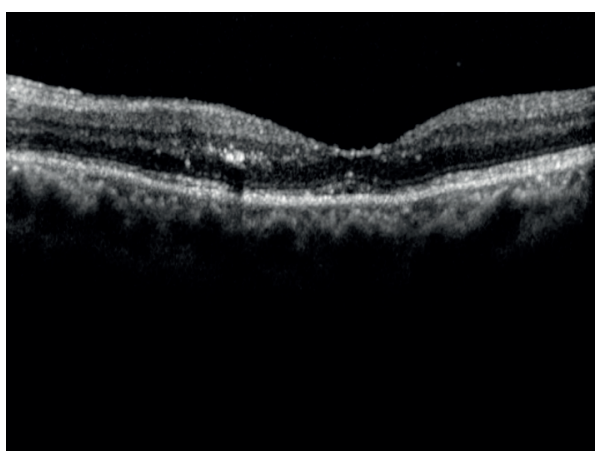

Fig. 4. Left eye OCT showing resolved macular oedema upon completed treatment.
Fig. 3. Left eye fundus photo showing well-defined optic disc with resolution of inferior disc margin.

based on the patient's age and comorbidities. However, the sudden onset of blurred vision and pain on eye movement were more suggestive of optic nerve inflammation, as was confirmed by serology.

Antibiotics form the mainstay of treatment. Azithromycin is preferred due to its ability to be concentrated in phagocytic cells, which enhances its efficacy, especially against intracellular pathogens like $T$. gondii and B. hensalae. ${ }^{5}$ Both ocular toxoplasmosis and bartonellosis have good visual prognosis with treatment. Huang et al. reported in 2017 that final visual acuity of $20 / 40$ or better was achieved in $74 \%$ of patient with ocular toxoplasmosis. ${ }^{6}$ Tan et al. reported that $76.9 \%$ of patients with ocular bartonellosis in Malaysia had a final visual outcome of 6/18 or better. ${ }^{7}$ From our literature search, most reported cases were single infections either by $T$. gondii or B. hensalae. We could not find concurrent dual organisms T. gondii and $B$. hensalae causing neuroretinitis being reported. 


\section{Conclusion}

Toxoplasmosis gondii and Bartonella hensalae may cause co-infection in endemic areas. The identification of causative organisms will facilitate the management and provide better outcomes.

\section{References}

1. Nissapatorn V, Abdullah KA. Review on human toxoplasmosis in Malaysia. Southeast Asian J Trop Med Public Health. 2004;35(1):24-30.

2. Switzer AD, McMillan-Cole AC, Kasten RW, Stuckey MJ, Kass PH, Chomel BB. Bartonella and Toxoplasma infections in stray cats from Iraq. Am J Trop Med Hyg. 2013;89(6):1219-1224.

3. Mokhtar AS, Tay ST. Molecular detection of Rickettsia felis, Bartonella henselae, and B. clarridgeiae in fleas from domestic dogs and cats in malaysia. Am J Trop Med Hyg. 2011;85(5):931-933.

4. Cunningham ET, Jr., Koehler JE. Ocular bartonellosis. Am J Ophthalmol. 2000;130(3):340-349.

5. Gladue RP, Bright GM, Isaacson RE, Newborg MF. In vitro and in vivo uptake of azithromycin (CP$62,993)$ by phagocytic cells: possible mechanism of delivery and release at sites of infection. Antimicrob Agents Chemother. 1989;33(3):277.

6. Huang PK, Jianping C, Vasconcelos-Santos DV, et al. Ocular toxoplasmosis in tropical areas: analysis and outcome of 190 patients from a multicenter collaborative study. Ocul Immunol Inflamm. 2017:18.

7. Tan CL, Fhun LC, Tai ELM, et al. Clinical profile and visual outcome of ocular bartonellosis in Malaysia. J Trop Med. 2017;2017:7946123. 